\title{
WOMEN AND ICT TRAINING: Inclusion or Segregation in the New Economy?
}

\author{
Hazel Gillard \\ Nathalie Mitev \\ London School of Economics \\ London, U.K.
}

\begin{abstract}
With the digital revolution narrated as the means for social cohesion in the globally competitive national economy, policy and corporate moves are afoot to increase the inclusion of women into the ICT arena, particularly those who have traditionally remained on the fringes of societal inclusion such as lone women parents. By equipping them with ICT skills, such as network engineering, and utilizing their "soft" relational expertise, greater employability and opportunity is seen as the route toward inclusion. Yet a tension emerges between policy and practice, where such women are finding it hard to gain work, for the ICT industry, renown for its long hours culture, is slow to implement government recommendations for greater work flexibility and their soft skills remain unrecognized. This paper positions this tension within a wider labor market background that focuses on part-time work, for a general lack of full-time flexibility means women with care responsibilities have a limited range of employment choice. Part-time employment is frequently reflective of dead-end jobs and a catalog of inequalities, where occupational segregation and discrimination point to the feminization of low-level ICT skills. This gendered relation to the labor market is hidden by the narrative of inclusion through ICT skills acquisition. Furthermore, the relational association reduces women and men to normative gendered identities and roles which will do little to challenge existing stereotypes of technical expertise. The paper concludes that rather than inclusion, the possible result is further gendered inequalities and exclusion.
\end{abstract}

\section{INTRODUCTION}

It is often argued that we now live in a new world brought together by new technologies, generating a "new economy" with a global reach (Castells 1996; Hanseth

Please use the following format when citing this chapter:

Gillard, H., and Mitev, N., 2006, in IFIP International Federation for Information Processing, Volume 208, Social Inclusion: Societal and Organizational Implications for Information Systems, eds. Trauth, E., Howcroft, D., Butler, T., Fitzgerald, B., DeGross, J., (Boston: Springer), pp. 185-202. 
and Braa 2000). In such an economy, ICT infusion, can impose corporate values and aspirations (Kallinikos 2001). Increasingly permeating our everyday existence and our social interaction, this ICT infusion has become "an expression of our interests, an implementation of our values, an extension of ourselves, a form of our lives" (Dahlbom 1996 , p. 14). This growth in global ICTs is accompanied by a belief in a series of interconnected socio-economic improvements for the socially excluded and the British nation. By enhancing employability through ICT skills acquisition, greater gender equity and inclusion will boost the nation's global economic competitiveness.

The growth of new technologies is supported by deregulation frameworks that liberalize the labor environment to ensure continued expansion across industrial sectors and enable cross-border migration. This deregulation market climate is woven in a context of ICT expansion and a privileging of knowledge work, where a shift in the West from factory work to white-collar service industries and office technology is said to herald the new economy. This background of ICT productivity plays a critical role in shaping demand for specific expertise, with citizens required to be cognizant of ICT skills, and this imperative generates issues around training and gender. A drive to update and reskill the British population is in full swing, with ICT proficiency seen to open up employment prospects, particularly for those deemed to be outside of mainstream society, and women form a large percentage of these socially excluded groups (Osborn et al. 2000; Rees 2002). "A vision of a modern, fairer and more prosperous Britain...means harnessing the skills and potential of every member of society" (Tony Blair, "Foreword" to DTI 2004). Regarded as the way to connect excluded groups to the new "information society," this harnessing requires that the nation's skills base keeps pace with ICT use in employment, and that strategic partnerships with relevant business, pedagogic and government bodies are built (DTI 2001).

This paper first briefly considers the ICT policy narrative on social exclusion and women's inclusion in Britain in the light of ICT training as a vehicle for social cohesion. We then examine a business-led ICT vendor-specific training scheme in place in many UK educational establishments, and present the narratives of women students enrolled in this training scheme.

\section{METHODOLOGY}

Data was gathered through in-depth interviews and participant observation (e.g., through attending instructor training modules) and from government and business documentation and conferences. In total, 48 people were asked to talk about their experiences and identify what they regarded as the most critical issues influencing the effectiveness of the ICT training course. The interviewees included three female representatives of the business organization and its public/private training program; four female and two male pedagogic managers or heads of department; four female and three male tutors; two female and one male trainee tutors; and twenty female and nine male students, of which seven were lone women parents. A narrative methodology was chosen to provide rich accounts within their localized settings, and to give expression to the hidden stories behind the statistics (Czarniawska 1998; Riessman 1993; Trauth 2002). 
During field work over a period of 9 months between 2002 and 2004, a crosssection of four educational sites was visited in South East England and Scotland: a higher education university, a further education institution, a women's technical college, and a women's technical and education center. These latter two educational institutions provide a second chance and a more flexible route toward education and employment for many who have been caught in the downward spiral of absenteeism from schooling, or have been labeled as "failures," or experienced low or semi-skilled work or unemployment. All of these educational establishments run the same standardized vendor-specific ICT training program in computer network engineering, although the style of delivery and supplementary content varied considerably. Our objective is to contrast the broader ICT policy and pedagogy narratives with the actual experiences of students and staff engaged with this training program, and to connect rhetoric with reality. The exclusion and inclusion policies within contemporary market dynamics claim to privilege ICT skills and gendered expertise, but what are women's actual experiences?

\section{ICT POLICY NARRATIVE: PRODUCTIVITY FOR THE NEW ECONOMY}

The infusion of ICT and the transformation of occupations have given rise to a perceived skills crisis on a global scale. A lack of key ICT professionals, such as network engineers, computer analysts, and programmers generates an anticipated 32 percent shortfall between demand and supply (Millar and Jagger 2001). An emphasis is that the workforce should not only be ICT literate, but also cognizant of relational expertise that is highly valued in the new economy's customer-oriented business environments, such as working in teams and communicative abilities. This skills shortage is regarded as a serious threat to the commercial exploitation of ICT, inhibitory of economic competitiveness, and reflective of an inability to adjust to change (DTI 1998; 2003a).

The government's solution is to turn round what it perceives as two key contributory factors to this skills shortage: a legacy of low skill levels, and the low participation of women in the labor market, particularly in the ICT sector (DfEE 1998; Greenfield et al. 2002). Deregulation of the labor market and the increased participation of women are key microeconomic strategies of the British government (DTI 2000, 2001, 2003a). Such strategies are seen to help kick-start the economy by facilitating greater work flexibility, and addressing the skills shortage and the high levels of social exclusion. To address the low skill levels, a key site for change is the restructuring of further education and training. The government's goal is that education becomes a life-long learning process; that vocationally oriented training programs and qualifications are standardized and consolidated, specifically those related to ICT; and that e-learning becomes more mainstream (DfEE 1998; DfES 2003). This new pedagogic culture promises "skills of the future" with enhanced job prospects, better pay and promotion, and flexible work arrangements. The British government, together with major ICT companies, is ensuring mechanisms are in place to train and retrain the workforce, specifically those who have traditionally stood outside employment like lone women 
parents. Reskilling the workforce and the socially excluded through vocational training has become the focus of both government and European policy and business attention, since there is an imperative to counterbalance a failure of supply to meet demand (DTI 1998; COM 2001, 2002). In the late 1990s, a doubling of ICT professions in Europe led to 10.26 million posts (Webster 2003b), generating a significant skills shortage that is predicted to rise by over 1.7 million in Europe alone (Rübsamen-Waigmann et al. 2002; Valenduc 2003). This shortage means "fishing from a wider pool," and finding new ways of working, combining both managerial, technical expertise, and relational expertise (Rübsamen-Waigmann et al. 2002, p. 5).

Britain has high levels of social exclusion, compared with the rest of Europe, with a poor inclusion record and lack of interdepartmental cohesion (Kennedy 1997; SEU 2004). The Social Exclusion Unit (SEU) was set up in 1997 to address this and coordinate policy formulation. The term social exclusion implies standing outside of mainstream society, and is indicative of a rupture in the social bond between sets of people and society (DFID 2002). It reflects an attempt to broaden analysis from a onedimensional view of poverty to include high levels of low skills, lone parent families, unemployment, poor housing, high crime rates, poor health and family breakdown that are seen to create deep-rooted, long-term social and economic problems (Durieux 2003; SEU 2004). Caught in these cycles of exclusion, people who have low educational achievement and a history of low labor market inclusion are positioned outside mainstream society.

Internet technology is seen as the way to combat such exclusion, with the narrative of a digital divide, or a "two speed eEurope" (CEC 2000), conveying an analysis of a division between those who have access to ICTs and those who don't. The digital divide is a dualism first coined by the Clinton administration in 1995 ( $\mathrm{Lu}$ and Wang 2003; Strover 2003). Those who lack access are perceived to be at risk of exclusion from the influx of new technological developments, and risk exclusion from the new economy (Castells 2001; Norris 2001). Access to the digital economy is today regarded as vital for better employment prospects and improved educational access, since the Net is seen as having the ability to "put the world at your fingertips" (Castells 1996).

With women perceived as being in danger of digital exclusion, they are being targeted for skills enhancement and labor market inclusion (Valenduc 2003; Webster 2003a). While the ICT sector is expanding in Britain, the level of women represented in it is decreasing, both in industry and academic disciplines (Panteli et al. 1999; Panteli, Stack, and Ramsey 2001; Robertson et al. 2001). This low participation by women is widely acknowledged in government circles to threaten Britain's productivity and global competitiveness (Rees 2002; Roberts 2001). Women are regarded as "the single biggest, most undervalued and underused human resource" (Greenfield et al. 2002, p. 36), and not to utilize them is to rob society of their diverse talents of communication, sharing, cooperation, forgiveness, and less ego-centered, pragmatic engagements with the world: the relational, soft skills in demand in today's customer oriented management (DTI $2003 \mathrm{~b}$; Webster 2003a). Women's inclusion is seen to offer them viable and marketable skills, thereby gaining economic independence and a viable career development. Not only will it improve their own personal circumstances, but it will also have beneficial impacts on their families (Rochlin and Boguslaw 2001). 
The wastage of women's skills as a result of the "leaky pipeline" and institutional discrimination that impedes women's careers is seen as a matter of urgency, since it holds constant across national and disciplinary boundaries (Osborn et al. 2000; Rees 2002; Rübsamen-Waigmann et al. 2002). In encouraging more women to enter the workforce, not only will they be able to tackle these legacies of wastage, but also diversify and improve the nation's skills base, foster excellence and innovation through the creation of new products, and strengthen market competitiveness (DTI 2003b; Rübsamen-Waigmann et al. 2002).

\section{ICT TRAINING FOR BUSINESS}

According to various British government bodies, the profusion of ICT means that new skills should be part of pedagogic curricula (DfES 2001; DTI 2002). This concern is linked to the narrative of demand for ICT skills that is outstripping an ability of education to produce them (DTI 1998, 2001, 2004b; DfEE 1999; DfES 2003; Millar and Jagger 2001). Therefore, an urgent need is radically overhaul the system to address the nation's low skill levels, with a reform of ICT teaching at NVQ (national vocational qualification) level 3 (DfES 2003; Fryer 1997). This is the level at which the network engineering module is pitched, and represents a relatively low-level ICT occupation. With identification and consolidation of key ICT skills regarded as critical (Dearing 1996; DfEE 1998; Kennedy 1997), the vendor-specific training program meets this requirement by providing a universal and standardized e-learning platform.

E-learning vendor programs are attractive because they offer multiple access points to education and training in ICT, and provide recognized qualifications. Both are argued to be paramount in encouraging career migration and transition, particularly for women with lower skills who may be facing redundancy, or hoping to return to the job market after a break (Fryer 1997; Greenfield et al. 2002). Understanding what the ICT industry needs is vital, with better career information and wider dissemination of the idea that most jobs today involve both ICT skills and face-to face customer interaction (DTI 2001; Millar and Jagger 2001).

An array of European directives on gender affirmative action policies and strategies, which the British government and many large ICT businesses endorse, constitute part of a drive toward digital citizenship and the feminizations of ICT (Osborn et al. 2000; Rees 2002). To support notions of difference and equity, changes in ICT stereotypes image and corporate culture are advocated to ease the strain of long, anti-social working hours and facilitate women's inclusion, with improved flexible work arrangements to enable a healthier balance between work and private responsibilities (Work and Parents Taskforce 2001). This change is designed to challenge assumptions about who engages with ICT work and the established masculine techno-culture which is "stuck in a time warp," as expressed by a business representative. The ICT company we studied makes use of marketing imagery by showing women in action-oriented roles and proactively attempts to recruit them into its training program. In the words of one ICT key business representative, we need to "educate people on how to be educated." The myth of ICT jobs as lacking human interaction, variety, or personal satisfaction this company regards as outdated, for the reality is that while programming or technical skills are required, a 
broader range around communication, teamwork and business awareness are key components. With this framework in mind, the paper now turns to the narratives of women on the network engineer training program, and highlights their actual experiences of this inclusion vehicle.

\section{NARRATIVES}

While the above policy and corporate strategies of inclusion appear to address the assumptions surrounding women's ICT exclusion, there seems to be mismatch between the perceived skills crisis and the reality of the ICT labor market, as narrated by a community education manager:

We weren't confident, we're still not confident, that what we 're providing from the daytime group is actually...in a position to avail themselves of that shortage... data we were given of ... the huge job shortage in this area, 80,000 vacancies...okay, that changed, partly because of the downturn in the economy... which did hit IT obviously...I think the shortage is certainly a lot less severe than it was.

This downturn in the ICT economy is reflected in the difficulty many students experience when seeking employment, as one male university student voiced:

A lot of the students are... actually worried [because] they don't have the experience, and most of them [employers] actually want l year experience, [or] 2 years experience....There isn't any work...the companies who are looking for people actually need $x$ amount of years in experience which...none of us I think [have].

Many students were not finding work after completion of the training program, as one woman community education manager expressed:

It's proving, for us, a very tough industry to break into, the technical, to develop the relationship with the employers...I suspect women going out into that situation are potentially going to find it tougher than the young men going out into that situation, [because] they're likely to go into departments where...the culture of the departments are very entrenched male cultures.

The lack of work experience and "entrenched male cultures" were particularly worrying for female students and staff in general, particularly since they were finding that the qualification was not recognized by ICT employers, as another community education manager commented:

The labor market doesn't necessarily agree with the qualification, not necessarily the qualifications we deliver but the qualifications in general...not particularly bothered about NVQs. 
This conundrum was articulated by another community education manager as reflecting the risk involved in letting a newly qualified yet inexperienced person work in a highly strategic networked environment:

The reality of the situation is most employers will not let the newly qualified person anywhere near their network system...employers are worried about [the] risk...to systems cock ups [errors] ... [there is a] general fear of failure.... Not surprisingly...it's very difficult to find appropriate work experience for somebody doing a qualification...nobody will let them near a network... [it's] very difficult to get the experience, very difficult to get your foot in the door, and without that it's very, very difficult to get a job... it is a real catch $22 \ldots$. This is indicative of the low risk attitude that we are finding, that the private sector is efficient and risk-taking...I find [that] laughable...they're immensely conservative... and in a way you can appreciate why... [because] if you've got somebody with 10 years experience and somebody who has just come out of college.... On the one level, you can understand them playing it safe...on the other level, perhaps they ought to be looking at potential rather than actual.... The two things are very, very different.

For women, the quest to find work was problematic given the industry's long working, anti-social hours, as narrated by a lone woman parent who simultaneously worked in the ICT industry and attended the program at university during her free time:

You cannot do IT to be fair if you have got children...you have to be 7 o'clock in the morning to turn up and make sure the backup is run and do the monthly backups. You have to run your child and drop her off at the child-minders... you just can't do that... if your network does go down and somebody needs to come out $10 \mathrm{o}$ 'clock at night...they're going to need you to be there and...if you were a single mother with a child, it would be virtually no way you could do that because where, where would you leave your child at 10 o'clock at night.

And if a student is a low-skilled, black, lone parent, employability is even more problematic, as a community education manager narrated:

Most employers would [employ]...graduates... in preference to a black, lone parent.

This racial, low-skilled, and care responsibility discrimination was not challenged in some pedagogic institutions, particularly with regard to gendered abilities, as the narrative of a male university head of department reveals:

The ladies of the class do have slightly different problems from the males because of their backgrounds and their experiences, and I do have this thing that, yes, females do think differently from males...I don't think I'm sexist in anyway but...men are more lateral thinking than women... with the sort of 
technical engineering type subjects...you can't just sort of look at the problem there [indicates a small area with hands], you've got to look that way as well [widens hands], what's going on around there...Think about what the engineers are doing, they don't...just look around there, they're looking over that hedge and over the next one and the third one as well. They are thinking ahead and programming, that's their way of thinking... you've got to put these things together and make them work...some women...they're not very confident... they're just not looking here [in front of his nose] ... and they can't look sideways either... a woman...doesn't seem to be able to do that.

The employability conundrum, combined with overt gendered stereotyping, is further reinforced by the lack of part-time work. An additional barrier for lone parents involved finding extra time to keep pace with constant changes in network information, as a woman parent and student narrated:

I really want to work part-time locally, but the industry is not here to do parttime work. Part-time work is like gold dust...If I had full-time work, I would have to employ someone to clean and iron....The problem with IT jobs is that they require continuous retraining. With a family how do you fit this in? The skills become obsolete. You go for a job and you're disadvantaged. I've been doing this for 20 years and technology is changing so fast. There used to be a plateau of skill levels but now there is no plateau any more....It adds pressure to you because of the family, I need to shop and cook and study.

Many socially excluded women with care responsibilities are disadvantaged when competing with male colleagues, as a lone woman parent and part-time university student, who had some experience of work interviews, remarked:

I'm also realistic to know that when it comes to interviews I'm sure that...if there is a man going with the same amount of experiences as me...they will take a man, so I'm realistic as well to know that it's not as easy to get a job in IT as a woman...as soon as you go into really technical...and network administration [work], I do think it's harder for you to get into those types of jobs...I'm sure, if you have a child I don't think, I don't think they would employ you, they won't say it, but I think that is the case.

This reveals many barriers: a shortage of employment, lack of network engineering experience, masculine techno-cultures, lack of qualification acknowledgment, fear of network malfunction, care conflicts, gendered and racial stereotyping, limited flexible work availability, the need to keep pace with technological advancements, and the industry's preference to recruit single men. Many students, particularly those with care commitments, realized that the ICT environment was not a particularly attractive arena, as a married student with two small children who had previously worked in banking narrated:

They [banking] were open to different ways of working, but I don't feel that has reached the male dominated computer world yet... it is inflexible in its 
working patterns....At the end of the day, my family comes first. I don't feel I'm available $24 / 7$.

The anti-social hours and the barriers reflect the ICT industry's recalcitrance in changing its competitive "new frontier" culture, and this is in evidence in terms of the onus on relational skills. These skills are not yet valued, as a male community education manager articulated:

It 's an extremely macho industry, the hours ... sort of new frontier culture...it's so unattractive, the role models are still... there's not really the focus on people skills that actually are increasingly important within the sector itself, but perhaps aren't being seen and recognized as being particularly important ... it is actually getting worse despite all these initiatives from employers.

These question the call for greater diversification of the workforce, and reinforce the argument that ICT skills acquisition alone is insufficient in addressing inclusion. Despite the policies and initiatives, the needs of business and students' expectations were mismatched, presenting a fundamental problem for pedagogy. The general lack of students' awareness, particularly women's, of what the ICT industry entailed was expressed by a head of business development in a community education college:

There's an incongruency of women and the hard reality... [there is a] lack of awareness of the IT world... the reality of the networking environment...there is a mismatch of expectation...women have no concept of what the industry is like... [they] think that they can do the job, but the reality is when it comes to what does that mean to their lives, they often aren't able to fit that in with their lives.... Much of the work is shift based, call-center, 24 hour cover... [there are problems in] bringing women in raw to IT, [they have] no skills, no IT skills, not much work experience in the industry.

This mismatch was summarized by a single woman student, aware of some of her colleagues' care responsibilities:

[This is] the whole contradiction...I feel the majority of their funding is based on maybe women getting back, single mothers getting back into work...it's going to be shifts...there you have the wonderful contradiction...I mean I appreciate what the man [a manager] said because part of it is true... networking is a 24/7 thing...it's not a 9 to 5 and "oh little Johnny's got a cold today." Tough!

Students are unprepared for the realities of the industry, and unsurprisingly frustration and annoyance emerged, as one single woman strongly articulated:

All these so called incentives-we want more women in engineering; we want more women in IT; we want more women in this... it's lip service...the bottom line is [that] if you happen to be a woman, that's what you want to do, you'll do it....This is what the government is always whittering [talking] on about, 
mothers and children and education, and get them off the dole [welfare benefit].

ICT inclusion programs, therefore, run the risk of reinforcing low-self esteem, disenfranchisement, and exclusion, as one lone woman parent student remarked:

The course is geared to attract single mums but...they're obviously targeting women who haven't got a clue until they get halfway through the course, and they realize "hold on a minute"... if they start investigating on jobs and issues and what's realistically out there... they'd given you false information because they wanted bums on seats...it's money... a computer conveyor belt...don't throw me in at the deep end [to] drown basically... Ineed a job that isn't going to take up much time as I don't have the support...they knew my situation, this is what's so frustrating, they knew it was difficult for me...I was naïve... it's frustrating when you know you can achieve something...there's no support... they've made me feel [extremely undermined], and that's just killed me...these women like me who are thinking of getting out of the rat race...they're demotivating me...they're setting us up to fail... at the end of the day, it's down to us.

These themes appear in all our geographical sites, rural and urban, across educational institutions, across ethnicity, age, parenthood, and experience. For women, especially as lone parents, these commonalities include negative notions of selfconfidence, the poor prospects of working in the ICT industry, their pressing childcare responsibilities, and consequently their sense of identity and range of possibilities, which do not necessarily fit with the policy and corporate narratives of inclusion.

\section{DISCUSSION: A POLITICAL ECONOMY OF WOMEN AND THE LABOR MARKET}

To understand how this mismatch between policy and practices emerges, an overview of women's relation to the labor market helps. Historically, there has been a legacy of gendered labor inequalities, in part because women continue to remain the primary care providers (Walby and Olsen 2002; Wallace 2002). For many, particularly those married, access to full-time work has been restricted by the view that they are not primary workers (Walby 1997; Walby and OIsen 2002). This legacy is displayed in women's disproportionate representation in part-time employment, and in their clustering in a limited range of low-level ICT occupations. This reflects a political economy of women's labor characterized by inequalities and rigidities that manifest a contradictory relation to productivity.

In 2000 , five times as many women (44 percent) as men ( 9 percent) were economically active in part-time employment in Britain (Cousins and Tang 2002; DfES 2003; Walby and Olsen 2002); a statistic which held for 2004 (National Statistics 2004). This heavy representation of women in part-time work is due to a lack of flexibility in full-time employment, and the acute shortage in affordable and suitable care arrange- 
ments (Walby 1990, 1997; Webster and Valenduc 2003). With Britain having the lowest childcare provision compared to other European nations, this presents a major obstacle to their inclusion (Cousins and Tang 2002; Kennedy 1997). Women's lower levels of education and training means part-time work may be their only option (Rees 1992; Walby and Olsen 2002; Wallace 2002). Such work is generally low or semiskilled, with less status than full-time employment, and poorly unionized (DTI 2002; Rubery et al. 1999).

A pay differential of 40 percent in 2002, rising to 43 percent in 2005 is common in part-time employment (Bulman 2002; Hibbett and Meager 2003). This also extends to women in full-time work, on average, being paid 18 or 19 percent less than their male counterparts (DfES 2003; Walby 1997). Part-time work tends to miss out on in-house training and has limited promotion opportunities, with many women's skill levels not increasing in comparison to those in full-time posts (DTI 2002; Walby and Olsen 2002). These pay differentials are attributable to women's lack of labor market experience, a result of interrupted employment, largely due to care responsibilities (Rees 1992; Walby and Olsen 2002). Unless women are protected by maternity leave, many experience downward mobility when they reenter the labor market, where their skills are underutilized and the number of children having a detrimental effect on their earnings (Rees 1992; Rubery et al. 1999; Walby and Olsen 2002).

Flexible work, for many women, is characterized by low skills, inequalities of pay, weaker conditions of service, fewer training and promotion opportunities, lower status, little labor protection, and greater instability (Cousins and Tang 2002; Greenfield et al. 2002). These have an adverse influence on productivity by poorly utilizing their skills and restricting their labor market mobility (Walby and Olsen 2002). Additionally, the ICT industry is not renown for regular part-time employment. It is not viewed as suited to part-time, flexible employment, with only 18 percent of workers not on full-time conditions of service in 2000 , of which 15.7 percent were women and 2.3 percent men (Millar and Jagger 2001). The industry has been slow to adopt work flexibility, with line managers resistant to change and unable to see the business case (DTI 2002; Walby and Olsen 2002). Concerned with the cost of additional recruitment, difficulties in managing a remote team, and the complexity in juggling projects, resources and changing customer requirements tend to govern working conditions and reduce choice in flexible working arrangements (DTI 2002; Vendramin 2003). With call availability in network engineering often over a 24-hour period 7 days a week, regular part-time work is viewed as inadequate.

Part-time contracts are most prolific in call centers, characterized by poor or absent unionization, staffed by low skilled women, under adverse conditions and poor remuneration (Belt et al. 2000; Wilson and Greenhill 2004). Finding part-time network engineer work is like finding gold dust. Breaks in employment mean that an employee will have to catch up on ICT knowledge and practices (Millar and Jagger 2001; Walby and Olsen 2002). This pressure is further amplified by a perception that either you have a dedicated, successful career or you have a balanced life (DTI 2002; Kodz et al. 2002). Being seen as less committed, an employee will be disadvantaged in the light of company practice to promote people abreast with ICT trends, rather than face the expense of updating skills.

In addition, the ICT sector displays a gendered segregation, which curtails the scope and potential for employability for women with care responsibilities (Rubery et al. 1999; 
Walby 1990, 1997; Webster 2003b). Women run the risk of being excluded in sites of increasing technical ghettoization (Wajcman 1991; Wilson and Howcroft 2000). This pattern of exclusion points to the feminizations of low-level ICT skills, where women are excluded from higher level positions (Rees 1992). Women still push the buttons but rarely engage with the more status oriented design or configuration of new technologies (Cockburn 1983, 1985; Wajcman 1991; Rees 1992).

This snapshot of low-skilled women in relation to the labor market, and the lack of suitable and regular part-time employment in the ICT sector, points to a contradiction that underpins the strategies to include socially excluded women, and at its heart lies the narrow focus on ICT employability. That women's employment is cataloged by inequalities is not fully accounted for by strategies of inclusion that pander to superficial narratives on legacies of low skill levels and the low participation of women. Yet, while these inequalities may jeopardize productivity, there appears to be an interdependence between the nation's competitive edge and women's cheaper, more flexible forms of labor (Cockburn 1985; Wajcman 1991; Walby 1990). By unraveling yet another labor market rigidity -discrimination (Rees 1992; Walby 1990, 1997; Webster 2003b)-we may begin to understand the recalcitrant inequity characteristics of many women's engagement with the labor market. This rigidity is brought to the fore by the association of women and relational expertise, and points to the symbolic and essentialist reinforcement of exclusionary mechanisms.

The ICT industry, renown for its youthful, masculine techno-culture, is a hard and unfriendly environment for women to enter or succeed in (Bowker and Star 2000; Faulkner 2000; Moreau 2003), despite equity and diversity legislation. While some women do manage to mold a career (Adam 1997; Henwood 2000), the ICT arena generally presents an unattractive and competitive new frontier philosophy that is not only recalcitrant to new initiatives, but also to recognizing relational skills. Enhanced employability for women through their perceived relational strengths does not take place for these skills tend not to be recognized, or rewarded (Rees 1992; Webster 2003a). Rather, what emerges during the feminizations of a particular occupation is the lowering of skills status, or deskilling (Rees 1992).

\section{CONCLUSION}

This paper sought to present an account of ICT inclusion policies with particular regard to network engineer training, and to match the rhetoric with the reality for socially excluded people, particularly women and lone parents. Our findings show that inclusion is not as straightforward as equipping the socially excluded with the required skills to open doors to their employability, for, in the case of women, the ICT industry remains recalcitrant in recognizing their value, preferring to recruit men (Millar and Jagger 2001; Rees 1992; Webster 2003b). This practice will not be challenged by the association of women and relational skills, since their value is seen to reside not in their technical expertise, but in symbolic personal and behavioral characteristics (Payne 1999). This symbolic association totters dangerously close to essentialism by reducing women to their "feminine" qualities (Faulkner 2000, 2004; Rommes and Faulkner 2003), and is reflected in strategies that attempt to feminize ICT by revamping ICT's 
masculine image through stereotyped notions of what women and young girls are perceived to be interested in. Yet the reality is that the industry is a male preserve, and any attempt to portray it as otherwise risks further disenfranchisement for those who do not fit or accept the normative and gendered practices. Equality of opportunity cannot be women's reality within this model of inclusion, for by homogeneously presenting them as relational, their differences are sidelined and invalidated.

By so shaping women's inclusion through recognition of their soft relational skills, normative gendered identities and roles are affirmed and differences are silenced (Bowker and Star 2000; Webster 2003b). This narrative of inclusion gives concreteness to women's and men's immutable natural abilities, denies other strengths, the gender crossing of skills, and positions women in low skilled, low status work and outside of technical expertise. In affirming essentialist skills to particular genders, historical and socio-political legacies of value are perpetuated and reinforced, and while society may then appear ordered and known, individuals struggle to find their place or be heard. Difference is silenced by this Western canon of purity (de Beauvoir 1972).

If marginality, or exclusion, is about not fitting into practices and beliefs perceived as the norm, and about crossing the borderlands of these recalcitrant narratives (Bowker and Star 2000), then how may socially excluded groups achieve inclusion if these borderlands of difference and ambiguity are silenced? The narratives of diversity and equity, while seeking to validate difference, do the opposite by imposing essentialist, socially constructed characteristics, in this case, of gender. By materially reinforcing gendered symbolic values in economic and technical deterministic inclusion, normative roles and identities seamlessly disappear into black-boxed infrastructures and discriminatory practices of taken-for-granted habit (Bowker and Star 2000). The monocausal government analysis of exclusion, where the key to a more prosperous and healthier life lies in employability through ICT skills acquisition, belies the complexity of why people continue to remain on the fringes of society. For some, it is a choice; for others, the choice is constituted by discrimination and a catalog of inequalities and barriers that the narratives reflect and policy does not.

Contrary to the narratives of inclusion, the labor market dynamics present fundamental tensions for people classified as socially excluded, and its deregulation may serve to jeopardize rights hard won. In formulating economic citizenship into educational arenas through the narratives of equality and diversity, socially excluded citizens are encouraged to cultivate an ethos of individualization, responsibility, and obligation, one that requires full ownership and accountability for the management of their personal socio-economic circumstances (Bauman 2000; Beck and Beck-Gernsheim 1995; Lister 1997). This ethos may not so easily be fostered for those on the fringes of society, for the reality of inclusion in terms of suitable and well-paid ICT employment continues to elude them. In assuming equality if skills acquisition is offered, the policy narrative of inclusion airbrushes the labor market relation that many women, particularly those with care responsibilities, experience, airbrushes their different needs and aspirations and thereby risks reinforcing their exclusion. 


\section{References}

Adam, A. "What Should We Do with Cyberfeminism?," in R. Lander and A. Adam (eds.), Women in Computing, Exeter, UK: Intellect Books, 1997, pp. 17-27.

Bauman, Z. Liquid Modernity, Cambridge, UK: Polity Press, 2000.

Beck, U., and Beck-Gernsheim, E. The Normal Chaos of Love, Cambridge, UK: Polity Press, 1995.

Belt, V., Richardson, R., and Webster, J. "Women's Work in the Information Economy," Information, Communication \& Society (3:3), 2000, pp. 366-385.

Bowker, G., and Star, S. L. Sorting Things Out, Cambridge, MA: The MIT Press, 2000.

Bulman, J. "Patterns of Pay: Results of the 2002 New Earnings Survey," Labor Market Trends (110:12), 2002, pp. 634-655.

Castells, M. The Internet Galaxy: Reflections on the Internet, Business and Society, Oxford, UK: Oxford University Press, 2001.

Castells, M. The Rise of the Network Society, Oxford, UK: Blackwell Publishers, 1996.

CEC. "Building an Inclusive Europe," Communication from the European Commission, Brussels, 2000.

Cockburn, C. Brothers: Male Dominance and Technological Change, London: Pluto Press, 1983.

Cockburn, C. Machinery of Dominance: Women, Men and Technical Know-How, London: Pluto Press, 1985.

Cousins, C., and Tang, N. "The United Kingdom" in C. Wallace (ed.), Households, Work and Flexibility: Critical Review of Literature, Vienna: HWF Series of Project Research Reports, HWF Research Consortium, 2002.

COM. "The eLearning Action Plan: Designing Tomorrow's Education," Commission of the European Communities, Brussels, 2001

COM. "eEurope 2005: An Information Society for All," Commission of the European Communities, Brussels, 2002.

Czarniawska, B. A Narrative Approach to Organization Studies, Thousand Oaks, CA: Sage Publications, 1998.

Dahlbom, B. "The New Informatics," Scandinavian Journal of Information Systems (8:2), 1996, pp. 29-47.

de Beauvoir, S. The Second Sex, Harmondsworth, UK: Penguin Books, 1972.

Dearing, R. "Review of Qualifications for 16-19 Year Olds," The Robert Dearing Report, London: Skills Council Academic Authority, 1996.

DfEE. "The Learning Age: A Renaissance of a New Britain," Green Paper, Department for Employment and Education, Nottingham: DfEE Publications, February 1998.

DfEE. "Skills for the Information Age," The Stevens Report, Department for Employment and Education, Nottingham: DfEE Publications, 1999.

DfES. "Skills for Life-The National Strategy for Improving Adult Literacy and Numeracy," Department for Education and Skills (Department of Employment and Education), London, 2001.

DfES. " $21^{\text {st }}$ Century Skills: Realising Our Potential," Department for Education and Skills (Department of Employment and Education), London, 2003.

DFID. "Social Exclusion in Pro-Poor Infrastructure Provision," Department for International Development, London, 2002.

DTI. "Excellence and Opportunity-A Science and Innovation Policy for the $21^{\text {st }}$ Century," Department for Trade and Industry, London, 2000.

DTI. "Fairness for All: A New Commission for Equality and Human Rights," White Paper, Department of Trade and Industry, in association with the Department for Constitutional Affairs, Department for Education and Skills, Department for Work and Pensions, and the Home Office, London, 2004 (available online at http://www.womenandequalityunit.gov.uk/). 
DTI. "Maximising Returns to Science, Engineering and Technology Careers," A report for the Office of Science and Technology and the Department of Trade and Industry, prepared by People Science and Policy Ltd. and the Institute for Employment Research, University of Warwick, 2002.

DTI. "Opportunity for All in a World of Change," White Paper, Department for Trade and Industry, London, 2001.

DTI. "Our Competitive Future: Building the Knowledge Driven Economy," Department for Trade and Industry, London, 1998.

DTI. "A Strategy for Women in Science, Engineering and Technology," Department for Trade and Industry., London, 2003a (available online http://extra.shu.ac.uk/nrc/section_2/ publications/reports/R1428_Strategy_for_Women_in_SET.pdf).

DTI. "Women in IT Conference: Engaging \& Retaining for Success," Department of Trade and Industry and the Department of Education and Skills, London, January 22, $2003 \mathrm{~b}$.

DTI 2004

Durieux, D. "ICT and Social Inclusion in the Everyday Life of Less Abled People," Key Deliverable, European Media and Technology in Everyday Life Network, 2003.

Faulkner, W. "Strategies of Inclusion: Gender in the Information Society," Symposium on Gender and Information and Communication Technologies: Strategies of Inclusion, Brussels, January 2004.

Faulkner, W. "The Technology Question in Feminism: A View from Feminist Technology Studies," Strategies of Inclusion: Gender and the Information Society, Brussels, 2000 (available online at http://www.rcss.ed.ac.uk/sigis/).

Fryer, R. H. "Learning for the Twenty-First Century," The Fryer Report, White Paper, First Report of the National Advisory Group for Continuing Education and Lifelong Learning, London, 1997.

Greenfield, S., Peters, J., Lane, N., Rees, T., and Samuels, G. "SET Fair: A Report on Women in Science, Engineering and Technology," The Greenfield Review, commissioned for the Department of Trade and Industry, London, November 2002.

Hanseth, O., and Braa, K. "Globalisation and 'Risk Society," in C. U. Ciborra and Associates (eds.), From Control to Drift: The Dynamics of Corporate Information Infrastructures, Oxford, UK: Oxford University Press, 2000.

Henwood, F. "From the Woman Question in Technology to the Technology Question in Feminism: Rethinking Gender Inequality in IT Education," The European Journal of Women's Studies (7), 2000, pp. 209-227.

Hibbett, A., and Meager, N. "Key Indicators of Women's Position in Britain," Labor Market Trends (111:10), 2003, pp. 503-511.

Kallinikos, J. "Recalcitrant Technology: Cross-Contextual Systems and Context-Embedded Action," Working Paper 103, London School of Economics and Political Science, 2001.

Kennedy, H. "Learning Works: Widening Participation in Further Education," The Further Education Funding Council, London, 1997.

Kodz, J., Harper, H., and Dench, S. "Work-Life Balance: Beyond the Rhetoric," IES Report 384, Institute for Employment Studies, March 2002 (available through http://www.employment-studies.co.uk/pubs/)

Lister, R. "Citizenship: Towards a Feminist Synthesis," Feminist Review (57), 1997, pp. 28-48.

$\mathrm{Lu}, \mathrm{A}-\mathrm{X}$., and Wang, H. "The Problems and Prospects of Teaching in the Digital Age," panel presentation to the Informing Science and Information Technology Education Joint Conference, Pori, Finland, June 24-27, 2003.

Millar, J., and Jagger, N. "Women in ITEC Courses and Careers," A report for the Department of Trade and Industry, Department for Education and Skills, and Women and Equality Unit, Suffolk, UK: DfES Publications, 2001. 
Moreau, M-P. "Work Organization and Working Conditions" in P. Vendramin, G. Valenduc, C. Guffins, J. Webster, I. Wagner, A. Birbaumer and M. Tolar (eds.), Conceptual Framework and State of the Art: Widening Women's Work in Information and Communication Technology, Namur, Belgium: Foundation Travail-Université, 2003 (available online at http://www.ftu-namur.org/www-ict).

National Statistics. "Labor Market Statistics," Office for National Statistics, London., June 2004. (http://www.statistics.gov.uk).

Norris, P. Digital Divide: Civic Engagement, Information Poverty, and the Internet Worldwide, Cambridge, UK: Cambridge University Press, 2001.

Osborn, M., Rees, T., Bosch, M., Ebeling, H., Hermann, C., Hilden, J., McLaren, A., Palomba, R., Peltonen, L., Vela, C., Weis, D., Wold, A., Mason, J., and Wenneras, C. "Science Policies in the European Union: Promoting Excellence through Mainstreaming Gender Equality," A report from the ETAN Network on Women and Science, Office for the Official Publications of the European Communities, Luxembourg, 2000.

Panteli, N., Stack, J., Atkinson, M., and Ramsey, H. "The Status of Women in the UK IT Industry: An Empirical Study," European Journal of Information Systems (8), 1999, pp. 170-182.

Panteli, N., Stack, J., and Ramsey, H. "Gendered Patterns in Computing Work in the Late 1990s," New Technology, Work and Employment (16:1), 2001, pp. 3-17.

Payne, J. "All Things to All People: Changing Perceptions of 'Skill' Among Britain's Policy Makers Since the 1950s and Their Implications," SKOPE Research Paper No. 1, Warwick University, 1999.

Rees, T. "The Helsinki Group on Women and Science: National Policies on Women and Science in Europe," Office for Official Publications for the European Communities:, Luxembourg, 2002.

Rees, T. Women and the Labor Market London: Routledge, 1992.

Riessman, C. K. Narrative Analysis, London: Sage Publications, 1993.

Roberts, G. "SET for Success: The Supply of People with Science, Technology, Engineering and Mathematical Skills," The Report of Sir Gareth Roberts' Review, London, 2001.

Robertson, M., Newell, S., Swan, J., Mathiassen, L., and Bjerknes, G. "The Issue of Gender Within Computing: Reflections from the UK and Scandinavia," Information Systems Journal (11), 2001, pp. 111-126.

Rochlin, S., and Boguslaw, J. "Business and Community Development: Aligning Corporate Performance with Community Economic Development to Achieve Win-Win Impacts," The Center for Corporate Citizenship at Boston College, 2001.

Rommes, E., and Faulkner, W. "Conclusion," in E. Rommes, I. van Slooten, E. van Oost, and N. Oudshoorn (eds.), Designing Inclusion: The Development of ICT Products to Include Women in the Information Society, Strategies of Inclusion: Gender and the Information Society, 2003 (available online at http://www.sigis-ist.org/).

Rubery, J., Smith, M., and Fagan, C. Women's Employment in Europe: Trends and Prospects, London: Routledge, 1999.

Rübsamen-Waigmann, H., Sohlberg, R., Rees, T., Berry, O., Bismuth, P., D'Antona, R., De Brabander, E., Haemers, G., Holmes, J., Jepson, M. K., Leclaire, J., Mann, E., Neumann, J., Needham, R., Christian, N., Vela, C., and Winslow, D. "Women in Industrial Research: A Wake Up Call for European Industry," A report for the European Commission from the High Level Expert Group on Women in Industrial Research for Strategic Analysis of Specific Science and Technology Policy Issues (STRATA), European Commission Directorate-General for Research, Luxembourg, 2002.

SEU. "Preventing Social Exclusion," A report by the Social Exclusion Unit, London, 2004 (available online at http://www.socialexclusionunit.gov.uk/). 
Strover, S. "Remapping the Digital Divide," The Information Society (19), 2003, pp. 275-277. Trauth, E. "Odd Girl Out: An Individual Difference Perspective on Women in the IT Profession," Information Technology and People (15:2), 2002, pp. 98-117.

Valenduc, G. "Mapping ICT Profession" in P. Vendramin, G. Valenduc, C. Guffins, J. Webster, I. Wagner, A. Birbaumer, and M. Tolar (eds.), Widening Women's Work in Information and Communication Technology: Conceptual Framework and State of the Art, Namur, Belgium: Foundation Travail-Université, 2003 (avaialble online at http:/www.ftu-namur.org/wwwict).

Vendramin, P. "Describing the Various Dimensions of the Gender Gap in ICT Professions" in P. Vendramin, G. Valenduc, C. Guffins, J. Webster, I. Wagner, A. Birbaumer, and M. Tolar (eds.), Widening Women's Work in Information and Communication Technology: Conceptual Framework and State of the Art, Namur, Belgium: Foundation TravailUniversité, 2003 (avaialble online at http://www.ftu-namur.org/www-ict).

Wajcman, J. Feminism Confronts Technology, Cambridge, UK: Polity Press, 1991.

Walby, S. Gender Transformations, London: Routledge, 1990.

Walby, S. Theorizing Patriarchy, Oxford, UK: Blackwell Publishers, 1990.

Walby, S., and Olsen, W. "The Impact of Women's Position in the Labor Market on Pay and Implications for UK Productivity," Report to Women \& Equality Unit, London: DTI Publications, November 2002.

Wallace, C. "Overview" in C. Wallace (ed.), Households, Work and Flexibility: Critical Review of Literature, Vienna: HWF Series of Project Research Reports, HWF Research Consortium, 2002.

Webster, J. "Gender Issues in European Socio-Economic Research on the Information Society," in P. Vendramin, G. Valenduc, C. Guffins, J. Webster, I. Wagner, A. Birbaumer, and M. Tolar (eds.), Widening Women's Work in Information and Communication Technology: Conceptual Framework and State of the Art, Namur, Belgium: Foundation TravailUniversité, 2003a (avaialble online at $\mathrm{http}: / / \mathrm{www} . \mathrm{ftu}$-namur.org/www-ict).

Webster, J. "Working in the New Economy-The View from the Employee," UK Work Organization Network, London, 2003b.

Webster, J., and Valenduc, G. "Mapping Gender Gaps in Employment and Occupations" in P. Vendramin, G. Valenduc, C. Guffins, J. Webster, I. Wagner, A. Birbaumer, and M. Tolar (eds.), Widening Women's Work in Information and Communication Technology: Conceptual Framework and State of the Art, Namur, Belgium: Foundation TravailUniversité, 2003 (avaialble online at http://www.ftu-namur.org/www-ict).

Wilson, M., and Greenhill, A. "Gender and Teleworking Identities: Reconstructing the Research Agenda," in Proceedings of the $12^{\text {th }}$ European Conference on Information Systems, Turku, Finland, June 2004.

Wilson, M., and Howcroft, D. "The Role of Gender in User Resistance and Informatin Systems Failure," in R. Baskerville, J. Stage, and J. I. DeGross (eds.), Organizational and Social Perspectives on Information Technology, Boston: Kluwer Academic Publishers, 2000, pp. 453-471.

Work and Parents Taskforce. "About Time: Flexible Working," London, 2001 (available online at http://www.workandparentstaskforce.gov.uk).

\section{About the Authors}

Hazel Gillard is currently finalizing her Ph.D. at the London School of Economics, Department of Information Systems. Her research interests lie in government and corporate valorization of ICT productivity to tackle socio-economic and gendered exclusion; in the 
philosophy of technology; and in pedagogy as a vehicle for social and personal change. With a diverse background in social anthropology and computer science, she has taught extensively in a variety of public sector educational institutions, traveled widely and is also a shiatsu practitioner. Hazel can be contacted at h.gillard@lse.ac.uk.

Nathalie Mitev is a senior lecturer at the London School of Economics and has held previous lecturing positions at Salford University and City University in the UK. She has French postgraduate degrees, an MBA, and a Ph.D. Her research career initially concentrated on information retrieval and human-computer interaction and then moved to the organizational and social aspects of IS. She has published on IS implementation issues in small businesses, and the health, tourism, travel, and construction industries. Her theoretical interests are the social construction of technology and she has applied actor-network theory to analyzing IS failures. She is particularly interested in how social constructionist approaches contribute to critical IS research. Nathalie has published in major IS journals and conferences, including European Journal for Information Systems, Journal of Information Technology, Information Technology and People, the European Conference on Information Systems and the International Conference on Information Systems. She has been track chair for various conferences such as IRMA, ICIS, and Decision Sciences Institute. She is a visiting professor at Aarhus University School of Business in Denmark. Nathalie can be reached at n.n.mitev@lse.ac.uk. 